\title{
Ekonomik Büyüme, Karbon Emisyonu ve İnsani Gelişmişlik Arasındaki İlişki: Seçilmiş Akdeniz Ülkeleri ${ }^{1}$
}

\author{
Müge MANGA \\ Dr. Öğr. Üyesi, Erzincan Binali Yıldırım Üniversitesi \\ İktisadi ve İdari Bilimler Fakültesi, İktisat Bölümü \\ mangamuge@gmail.com \\ Orcid ID: https://orcid.org/0000-0003-2675-2182
}

\section{Pınar GÜMÜŞ AKAR}

Öğr. Gör. Dr., Gaziantep Üniversitesi, Havac1lık ve Uzay Bilimleri Fakültesi

Havacılık Yönetimi Bölümü

pinarga@gmail.com

Orcid ID: https://orcid.org/0000-0003-2793-8528

\begin{abstract}
$\ddot{\mathbf{O z}}$
$\mathrm{Bu}$ çalışmada, Avrupa Birliğinde yer alan Akdeniz Ülkeleri Hırvatistan, Kıbrıs, Fransa, Yunanistan, İtalya, Malta, Slovenya, İspanya ve Birlik içerisinde yer almayan Türkiye'deki ekonomik büyüme, karbon emisyonu ve insani gelişmişlik düzeyi arasındaki ilişkinin test edilmesi amaçlanmaktadır. Kurulan modelde yer alan değişkenler arasındaki ilişki, 1998-2014 yılları esas alınarak Panel ARDL yöntemi ile analiz edilmektedir. Elde edilen sonuçlar, seçilen ülkelerde Çevresel Kuznets Eğrisi hipotezinin geçerli olduğunu göstermektedir. Ayrıca yapılan analiz sonucunda, bu ülkelerdeki insani gelişmişlik indeksi ile karbon emisyonu göstergesi arasında negatif yönlü bir ilişkinin söz konusu olduğu sonucuna ulaşılmıştır.
\end{abstract}

Anahtar Kelimeler: Ekonomik Büyüme, Karbon Emisyonu, İnsani Gelişmişlik İndeksi.

\footnotetext{
${ }^{1}$ Makale Geliş/Kabul Tarihi: 18.04.2019 / 05.07.2019

Künye Bilgisi: Manga, M. ve Gümüş Akar, P. (2020). Ekonomik Büyüme, Karbon Emisyonu ve Insani Gelişmişlik Arasındaki İlişki: Seçilmiş Akdeniz Ülkeleri. Kahramanmaraş Sütçü İmam Üniversitesi Sosyal Bilimler Dergisi, 17 (1), 405-419. DOI: 10.33437/ksusbd.555415
} 


\title{
The Relationship Between Economic Growth, Carbon Emission and Human Development: The Case of Selected Mediterranean Countries
}

\begin{abstract}
In this study, in the European Union of Mediterranean Countries in Croatia, Cyprus, France, Greece, Italy, Malta, Slovenia, Spain and take part in the union that economic growth in Turkey, aims to test the relationship between carbon emissions and human development level. The relationship between the variables in the model is analyzed by ARDL method based on the years 1998-2014. The results show that the Ecological Kuznets Curve hypothesis is valid in selected countries. In addition, it is seen that there is a negative relationship between Human Development Index and carbon emission indicator in these countries.
\end{abstract}

Keywords: Economic Growth, Carbon Emission, Human Development Index.

\section{GíRiş}

Hava ve su kirliliğinin çeşitli türleri ile gelir arasındaki ilişkinin incelendiği literatür, gelir arttıkça çevre kirliliğinde iyileşmenin gözlendiğine yönelik bulgular içermektedir. Örneğin Grossman ve Kruger (1995) kişi başına düşen 8.000 Dolar düzeyindeki gelirin, çevre kirliliği açısından bir dönüm noktası olduğunu belirtmişlerdir. Çevresel kirlilik ve gelir arasındaki ters-U şeklindeki bu ilişki, Kuznets (1955) gelir eşitsizliği modeli ile benzerliği nedeniyle "Çevresel Kuznets Eğrisi ${ }^{2}$ (Ecological Kuznets Curve-EKC)" olarak da anılmaktadır. Politika analistleri, mevcut araştırmaların sonuçlarına dayanarak gelişmekte olan ülke (GOÜ) ekonomilerinin büyüdükçe daha temiz çevresel koşullara sahip olacakları, en fakir ülkelerin ise geliştikçe daha kötü çevresel koşullara sahip hale geleceklerine yönelik çıkarımlarda bulunmuşlardır. Bu tür çıkarımlar, çevresel kirliliğin deterministik ters-U şekilli Kuznets eğrisini izlediğine yönelik bir genel kabule dayanmaktadır (Harbaugh vd, 2002:541). Ekonomik büyümenin çevreye daha fazla zarar $\mathrm{m} ı$ vereceği ya da artan gelir ve servetin ekolojik sorunların iyileşmesine katkı mı sağlayacağı sorularının cevapları az gelişmiş ülkelerin (AGÜ) kalkınma stratejilerinin belirlenmesi açısından kritik bir öneme sahiptir. Belirlenen kalkınma stratejisi, birçok mal ve hizmetin üretiminde girdi olarak kullanılan yenilenebilen ve yenilenemeyen

${ }^{2}$ Literatürdeki yaygın kullanımı nedeniyle çalışma içerisinde EKC (Ecological Kuznets Curve) kısaltması ile kullanılacaktır. 
doğal kaynaklar, çıktı bileşimi, üretim yöntemlerinin değişebilir nitelikte olması üretim düzeyi ve çevreye verilen zarar ilişkisinin değişimi açısından önemlidir (Grossman ve Krueger, 1995:353).

Ekonomik büyüme ve çevresel bozulma arasındaki ilişkiye yönelik tartışmalı analizlerden olan EKC'nin temel mantığına göre kalkınmanın ilk aşamasında (sanayileşme aşaması) doğal kaynaklar yoğun olarak bozulmakta ve çevre kirliliği hızla artmaktadır. Bu aşamadan sonra ekonomik karar birimleri çevreyi korumadan ziyade daha yüksek çıktı düzeyi, istihdam oranı ve gelir elde etmeyi amaçlamaktadır. Hızlı ekonomik büyüme daha fazla doğal kaynak kullanımına neden olmakta ve bu durum çevre üzerinde bir baskı oluşturmaktadır. Sanayileşmenin sonraki aşamasında ise ekonomik büyüme ve buna bağlı olarak gelir arttıkça, önceki dönemlerde göz ardı edilen çevre kavramına verilen önem artmaktadır. Bu aşamalarda kamu kurumları daha etkin ve zorlayıcı çevre politikaları şekillendiğinden çevresel kalite artmaya başlar (Gürlük, 2009:2327).

Çıktı ve milli gelir düzeylerinde artış ile ifade edilen ekonomik büyüme, başlangıçta ekonomik kalkınma olarak algılanmıştır. Ancak daha karmaşık bir yapısının olduğu fark edilmiş ve bu bağlamda ekonomik kalkınmayı ifade etmeye yönelik başka ilave kriterler dikkate alınmaya başlamıştır. Bu çerçevede, nüfus artış hızının etkisini telafi etmeye yönelik "kişi başına düşen milli gelir" ve "gelir bölüşümü” kavramlarının en erken fark edilen kriterler olduğu söylenebilir. 1970'li yıllarda ise, "temel insani ihtiyaçlar" kriteri ön plana çıkmış ve bu ihtiyaçların karşılanması da kalkınmanın bir ölçütü haline gelmiştir. Bu aşamada konuya ilişkin bakış açısı kişi başına düşen milli gelirin yükseltilmesinden ziyade yerini fakirliğin azaltılmasına bırakmıştır. 1980'lerde ekonomik büyümenin yol açtığ 1 çevre sorunları ve "sürdürülebilir kalkınma" kavramı gündeme gelmiştir. 1990'larda ise "insani gelişme" kavramı temel ihtiyaçlar yaklaşımının bir uzantısı olarak ortaya çıkmıştır. Bu bağlamda "İnsani Gelişmişlik İndeksi ${ }^{3}$ ( Human Development Index- HDI)" gelirin yanı sıra, eğitim ve sağlık ihtiyaçlarının karşılanma düzeyini içeren bir kalkınma göstergesi olarak kullanılmaktadır (Orman, 2008:15-17).

Ekonomik büyüme ve çevre kirliliği arasındaki ilişkiyi EKC çerçevesinde inceleyen çok sayıda çalışma bulunmasına karşın [Shafik ve Bandyopadhyay (1992), Grossman ve Krueger (1995), Carson vd. (1997), Khanna ve Plassmann (2004), Song vd. (2008), Ahmed ve Long (2012), Shahbaz vd. (2012), Apergis ve Öztürk (2015), Jebli vd. (2016)] ekonomik kalkınma ve göstergelerinden biri olarak HDI ile çevre kirliliğine ilişkin göstergeler arasındaki ilişkiye yönelik daha

\footnotetext{
${ }^{3}$ Literatürdeki yaygın kullanımı nedeniyle çalışma içerisinde HDI (Human Development Index) kısaltması ile kullanılacaktır.
} 
kısıtlı sayıda çalışma bulunmaktadır [Gürlük (2009), Boutaud vd. (2006), Moran vd. (2008), Chen vd. (2010), Bedir ve Y1lmaz (2016)]. Bu amaçla mevcut çalışmada, belirli Akdeniz ülkelerinde çevre kirliliğinin, ekonomik büyüme ile ilişkisinin yanı sıra HDI ile ilişkisinin EKC hipotezinin test edilmesi çerçevesinde incelenmesi amaçlanmaktadır.

\section{LITERATÜR}

Ekonomik büyüme ile karbon emisyonu arasındaki ilişkiyi test eden birçok çalışmanın literatürde hakim olduğunu görmek mümkündür. Bu iki kavram arasındaki ilişkinin incelenmesinde Kuznets (1955) çalışmasından yola çıkılmıştır. Bu çalışmada, gelir eşitsizliği ile ekonomik büyüme arasında ifade edilen ters-U şeklindeki ilişkiye bağlı olarak, ülkelerin gelişim süreciyle birlikte gelir adaletsizliğinin azalacağı ifade edilmektedir (Kuznets, 1955:27). Aynı yönlü ilişkinin çevre kirliliği ve ekonomik büyüme arasında da söz konusu olacağını vurgulayan Grossman ve Krueger (1991) çalışmasında, NAFTA ile gerçekleşen ticari serbestleşmenin 32 farklı ülkede ortaya çıkan çevre kirliliği üzerindeki etkisini araştırmıştır. Yapılan çalışmada, araştırılan ülkelerde gerçekleşen ticaret akımı artışının ülkelerin gelişme evrelerinin ilk dönemlerinde kükürt dioksit ve "duman artışına bağlı olarak hava kirliliğinin yükseleceğini, ekonomik gelişimin sonraki aşamalarında ise hava kirliğinin azalacağı ifade edilmiştir (Grossman ve Krueger, 1991:1). Ayrıca Grossman ve Krueger (1995) çalışmasında da ülkenin kişi başına düşen gelir düzeyinin 8.000 Dolara (1985 y1lı sabit fiyatlarıla) yükselmesi öncesinde maksimum düzeyde çevre kirliliğinin söz konusu olacağını, sonrasında yaşanan kişi başına gelir artışa paralel olarak çevre kirliliğinin azalacağı ifade edilmiştir (Grossman ve Krueger, 1995:370) . Bu çalışmalarla birlikte dikkat çeken çevresel bozulma kavramı, Shafik ve Bandyopadhyay (1992) çalışmasıyla da desteklenmiştir. Bu çalışmada, gelir düzeyinde yaşanan değişimlerin çevre kalitesini etkileyen en temel faktör olduğu, gelir düzeyi arttıkça, çevresel göstergelerde en yüksek düzeyde bozulma gerçekleşirken, çevresel bozulmada ortaya çıkan sorunların daha yüksek gelir düzeyi gerçekleşince ortadan kalktığı vurgulanmıştır (Shafik ve Bandyopadhyay, 1992:1-21).

Genel olarak yapılan çalışmaların, çevresel kirlilik (karbon emisyonu) ile ekonomik büyüme arasındaki ilişkinin ülkelerin gelişmişlik düzeyine bağlı olarak değişim göstermesini ifade eden EKC hipotezinin test edilmesi üzerine odaklandığı görülmektedir. EKC hipotezine göre, ülke ekonomilerinde yaşanan ilk gelişme evresinde çevresel bozulma ve kirliliğin artacağını, ekonomik gelişmenin sonraki evrelerinde ise çevresel bozulma ve kirliliğin azalacağını dolayısıyla, çevre kirliği göstergesi olan karbon emisyonu ile kişi başına gelir arasındaki ilişkinin ters U- şeklini alacağını ifade etmektedir (Shahbaz vd. 2015:475). 
Bu çerçevedeki çalışmalardan, Apergis ve Öztürk (2015) çalışmasında, 19902011 yılları arasındaki 14 Asya ülkesindeki EKC hipotezinin testi GMM metodu ile incelenmiştir. Elde edilen sonuçlar, bu ülkelerde EKC hipotezinin geçerli olduğunu ortaya koymaktadır. Jebli vd. (2016) çalışmasında, 1980-2010 yılları arasında OECD ülkelerinde EKC hipotezinin geçerli olduğu sonucuna ulaşılmıştır. Song vd. (2008), 1985-2005 yılları arasındaki Çin ekonomisinde EKC hipotezinin geçerli olup olmadığını DOLS ve WOLS yöntemleri ile analiz etmişlerdir. Yapılan çalışmada elde edilen test sonuçları, Çin ekonomisinde EKC hipotezinin geçerli olduğunu göstermektedir. Ahmed ve Long (2012) ve Shahbaz vd. (2012) çalışmasında, Pakistan ekonomisinde EKC hipotezinin geçerliği ARDL yöntemleri kullanılarak test edilmiştir. Yapılan çalışmada Pakistan ekonomisinde seçilen dönemlerde EKC hipotezinin geçerli olduğu sonucuna ulaşılmıştır. Genel olarak ifade edilmesi gerekirse, gelişmiş ülkelerden ABD için yapilan Carson vd. (1997), Khanna ve Plassmann (2004), Tzeremes (2018) çalışmalarında EKC hipotezi test edilmiştir. Başar ve Temurlenk (2007), Akbostanc1, vd. (2009), Soytas ve Sarı (2007) ve Lise (2006), Bölük ve Mert (2014), Katircioğlu ve Taşpinar (2017), Aydın ve Esen (2017), Yurttagüler ve Kutlu (2017), Ozcan, vd. (2018) ve Lebe (2016) gibi çalışmalarda Türkiye için, Rusya için ise Ketenci (2018), G7 ülkeleri için Ajmi vd. (2015), Malezya ülkesi için Bello vd. (2018), 145 farklı ülke grubu için Melikhova ve Č́žžek (2014) ve York vd. (2003)'te ise 1996 yılındaki 142 ülke için EKC hipotezinin test edilmesi amaçlanmıştır.

Mevcut literatürde, ülkelerin kişi başına gelir düzeyleri ile karbon emisyonu arasındaki ilişkiyi ele alan diğer bir ifadeyle EKC hipotezini test eden birçok çalışmanın yer aldığı görülmektedir. Ancak, ekonomik büyüme ile karbon emisyonu ve ülkelerin birçok açıdan gelişmişlik düzeyini gösteren HDI ile arasındaki ilişkiyi test eden çalışmaların azınlıkta olduğu görülmektedir. Boutaud vd. (2006) çalışmasında 131 ülke için iki farklı model yardımıyla EKC hipotezinin test edilmesi amaçlanmıştır. Kurulan ilk modelde, ekolojik ayak izi (ecological footprint - EF) ile ekonomi büyüme arasında ilişki tahmin edilmeye çalış1ırken, ikinci modelde HDI ile EF arasında ilişki kurulması amaçlanmıştır. Yapılan çalışmada, EKC hipotezinin geçerli olmadığı, EF'nin ülkelerin gelişimlerinin ilk evrelerinde artmadığı, HDI'nin 0.600-0.750 aralığında olması durumunda kayda değer bir artışın ortaya çıkmayacağı, 0.750 üzerine çıkması durumunda EF'nin bir miktar artı̧̧ göstereceği ifade edilmiştir. Moran vd. (2008) çalışmasında, 1975-2003 yılları arasındaki 93 ülkedeki EF ile HDI arasında pozitif yönlü bir ilişkinin söz konusu olduğu diğer bir ifadeyle seçilen ülkeler için EKC hipotezinin geçerli olmadığ 1 ifade edilmiştir. Ayrıca yapılan çalışmada, özellikle gelişmiş ülkelerin sürdürülebilir kalkınma ve büyüme trendinden uzak hareket ettiği vurgulanmıştır. Chen vd. (2010) çalışmasında, doğal kaynak kullanımı ile sosyal kalkınma arasında ilişkinin kurulması amaçlanmıştır. 19962005 yılları arasındaki 136 ülkedeki kişi başına düşen ekolojik ayak izi, enerji ve 
doğal kaynak kullanımından kaynaklı ayak izi ile gelişmişlik göstergesi olarak kullanılan HDI arasında U şeklinde bir ilişkinin söz konusu olduğu, bu nedenle EKC hipotezinin desteklenmediği ifade edilmiştir. Ayrıca doğrudan, karbon emisyonu HDI değişkeni arasındaki nedensellik ilişkisini tespit etmeyi amaçlayan Bedir ve Yılmaz (2016) çalışmasında, 1992-2011 yılları arasındaki 33 OECD ülkesi için panel nedensellik testlerinden faydalanılarak, Danimarka, İrlanda, İsrail, İtalya, Japonya, Kore, Lüksemburg, Polonya, İspanya, Slovakya, Türkiye ve ABD'de enerji kullanımının HDI'yi negatif yönde etkilediği, Şili, Çek Cumhuriyeti, Estonya, Finlandiya, Fransa, Yunanistan, Meksika ve Yeni Zelanda karbon emisyonundaki değişimlerin HDI üzerinde negatif yönlü bir etkisinin olmadığı, İzlanda, Norveç, Portekiz ve İsviçre'de iki gösterge arasında karşılıklı ilişkinin söz konusu olduğu, Avustralya, Avusturya, Belçika, Kanada, Macaristan, Hollanda, Slovenya, İsveç ve İngiltere'de ise karbon emisyonu ile HDI arasında ilişkinin söz konusu olmadığı sonucuna ulaşılmıştır. Gürlük (2009) çalışmasında, çeşitli zaman aralığındaki seçilmiş Akdeniz ülkelerindeki ekonomik büyüme, endüstriyel kirlilik ve HDI arasındaki ilişki analiz edilmiştir. Yapılan çalışma ile Fransa dışında tüm seçilen ülkelerde EKC hipotezinin geçersiz olduğu sonucuna ulaşılmıştır. Ayrıca, Ürdün ve Tunus dışında seçilmiş ülkelerde HDI ile endüstriyel kirlilik arasında negatif yönlü bir ilişki olduğu sonucuna ulaşılmıştır.

Yapılan bu çalışmada, literatürde yer alan diğer çalışmalardan farklı olarak Avrupa birliğinde yer alan seçilmiş Akdeniz ülkeleri ve birlik içerisinde yer almayan Akdeniz ülkelerinden olan Türkiye için Kuznets hipotezinin geçerliliği ve bu ülkelerde karbon emisyonu ile HDI göstergesi arasındaki ilişkinin test edilmesi hedeflenmektedir.

\section{VERİ, YÖNTEM VE BULGULAR}

Bu çalışmada, 1998-2014 yılları için Avrupa Birliği içerisinde ve Akdeniz ülkelerinden olan Hırvatistan, Kıbris, Fransa, Yunanistan, İtalya, Malta, Slovenya, İspanya ve Türkiye'deki ekonomik büyüme (LnGSYH), karbon emisyonu $\left(\mathrm{LnCO}_{2}\right)$ ve insani gelişme endeksi (LnHDI) arasındaki uzun ve kısa dönemli ilişki incelenmektedir. Çalışmada kurulan modelin belirlenmesinde Gürlük (2009) ve Bedir ve Yılmaz (2016) çalışmalarından faydalanılmıştır. Yapılan çalışmada kurulan modelde yer alan GSYH değerleri ile fosil yakıtların tüketilmesi ile ortaya çıkan $\mathrm{LnCO}_{2}$ değişkeni kişi başına 2010 yılı sabit \$ fiyatlarıyla Dünya Bankası veri tabanından elde edilmiştir. $\mathrm{HDI}^{4}$ verileri ise, $\mathrm{BM}$

\footnotetext{
${ }^{4}$ HDI değişkeni, (i)insani gelişme kalitesi; (ii) yaşam boyu toplumsal cinsiyet fark1; (iii) kadının güçlenmesi; (iv) çevresel sürdürülebilirlik; ve (v) sosyo-ekonomik sürdürülebilirlik göstergelerinden oluşan bir endekstir.
} 
Kalkınma Programı (UNDP)'ndan elde edilmiştir. Elde edilen veriler yardımıyla kurulan model;

$$
\operatorname{LnCO}_{2 t}=\delta_{0}+\delta_{1} \operatorname{LnGSYH}_{t}+\delta_{2} \operatorname{LnGSYH}_{t}^{2}+\delta_{3} \operatorname{LnHDI}_{t}
$$

şeklinde oluşturulmuştur.

Kurulan modelde yer alan değişkenler arasındaki ilişkinin belirlenmesinde Panel Birim Kök ve Panel ARDL (Autoregressive Distributed Lag Model) yönteminden faydalanılmıştır. Ancak, seçilen ülkeler üzerine parametre tahmininden önce seçilen ülke grupları arasında politik veya ekonomik anlamda herhangi bir yatay kesit bağımlılı̆̆ının olmadığının sinanmasında Pesaran (2004) testinden faydalanılmışırı. Yatay kesit sınamasında, $N>T$ olması durumunda ise Pesaran (2004) tarafindan türetilen ADF regresyonunun tahmininden elde edilen kalıntıların kullanıldığı CD testi kullanılmaktadır. CD testi hesaplamasında, her birimin kendisi dışında kalan tüm birimlerle otokorelasyonu hesaplanmakta ve $\mathrm{N}$ birim boyuttaki otokorelasyon sayıs1, $\mathrm{N} *(\mathrm{~N}-1)$ adete kadar hesaplanmaktadır. Dengeli panel için CD testi;

$$
C D=\sqrt{\left(\frac{2 T}{N(N-1)}\right)} \sum_{i=1}^{N-1} \sum_{j=i+1}^{N}\left(\hat{\rho}_{i j}-1\right) \sim N(0,1)
$$

şeklinde hesaplanmaktadır (Yerdelen Tatoğlu, 2017:105).

Modelde yer alan değişkenler için durağanlık testinde Panel Birim Kök testlerinden Pesaran (2007) tarafindan ortaya atılan CADF (Cross-Sectional Augmented Dickey-Fuller) testinden faydalanılmıştır. $\mathrm{T}>\mathrm{N}$ ve $\mathrm{N}>\mathrm{T}$ olması durumunda kullanılan CADF regresyonun en geneli,

$$
\Delta Y_{i t}=\alpha_{i}+\rho_{i} Y_{i, t-1}+\beta_{i} \bar{Y}_{t-1}+\sum_{j=0}^{k} \gamma_{i j} \Delta \bar{Y}_{i, t-1}+\sum_{j=0}^{k} \delta_{i j} Y_{i, t-1}+\varepsilon_{i t}
$$

şeklinde ifade edilmektedir. Yukarıdaki denklemde yer alan $\alpha_{i}$ deterministik trend, $\quad \bar{Y}_{t-1}=(1 / N) \sum_{i=!}^{N} Y_{i, t-1}$ ve $t_{i}(N, T), \quad \rho_{i}$ değeri için hesaplanan ADF istatistiğini vermektedir. CADF testinde durağanlığın sınaması aşağıdaki gibidir (Tatoğlu, 2017:85-86):

$$
\begin{aligned}
& H_{0}: \rho_{i}=0 \text { (tüm i'ler için) } \\
& H_{1}: \beta_{i}<0 \quad\left(\mathrm{i}=1,2, \ldots . \mathrm{N}_{\mathrm{i}}\right)
\end{aligned}
$$




$$
\rho_{i}=0\left(\mathrm{i}=\mathrm{N}_{\mathrm{i}+1}, \mathrm{~N}_{\mathrm{i}+2 \ldots \ldots, \mathrm{N})}\right.
$$

Ayrıca Pesaran (2007) tarafindan her bir yatay kesite ait (ülkelere) birim kök test istatistiklerinin ortalaması alınarak panelin geneli için hesaplanan birim kök testlerinden Yatay kesit genişletilmiş Im, Pesaran ve Shin (Cross-Sectionally Augmented IPS-CIPS) elde edilebilir. CADF istatistiğinin ortalaması olan CIPS aşağıdaki gibi hesaplanabilmektedir (Pesaran, 2007: 276).

$$
\text { CIPS }=\frac{1}{N} \sum_{i=1}^{N} t_{i}(N, T)
$$

$\mathrm{Bu}$ çerçevede değişkenler arasındaki uzun ve kısa dönemli ilişki Pesaran vd. (1999) tarafından geliştirilen Panel ARDL yöntemi ile analiz edilmiştir. Panel ARDL modeli grup tahmincisinin; havuzlanmış grup tahmincisi (pooled mean grup-PMG) ve grup tahmincisi (mean grup-MG) olarak çeşitli örnekleri söz konusudur. Yapılan çalışmada, belirlenen değişkenler arasındaki ilişki için kurulan panel ARDL denklemi;

$$
\begin{gathered}
C o 2_{i t}=\sum_{k=1}^{p} \operatorname{CO}_{i, t-k} \emptyset_{i k}+\sum_{k=0}^{q} G S Y H_{i, t-k} \partial_{i k}+\sum_{k=0}^{q} G S Y H_{i, t-k}^{2} \partial_{i k} \\
+\sum_{k=0}^{q} H D I_{i, t-k} \partial_{i k}+\mu_{i}+\varepsilon_{i t}
\end{gathered}
$$

şeklinde oluşturulmaktadır.

Ayrıca, Panel ARDL yöntemi için hata düzeltme modeli;

$$
\begin{aligned}
\mathrm{d} C O_{2(\mathrm{it})}=\mathrm{c}_{0} & +\sum_{\mathrm{i}=1}^{\mathrm{n}} \beta_{0, \mathrm{i}} \mathrm{d} C O_{2(\mathrm{t}-\mathrm{i})}+\sum_{\mathrm{i}=1}^{\mathrm{n}} \beta_{1, \mathrm{i}} \mathrm{dGSYH} \mathrm{t}_{\mathrm{t}-\mathrm{i}}+\sum_{\mathrm{i}=1}^{\mathrm{n}} \beta_{2, \mathrm{i}} \mathrm{d} G S Y H_{t-i}^{2} \\
& +\sum_{\substack{\mathrm{i}=1\\
}} \beta_{3, \mathrm{i}} \mathrm{dHDI}_{\mathrm{t}-\mathrm{i}}+\delta_{0} \mathrm{CO}_{2(\mathrm{t}-1)}+\delta_{1} \mathrm{GSYH}_{\mathrm{t}-1} \\
& +\delta_{2} G S Y H_{t-1}^{2}+\delta_{3} \mathrm{HDI}_{\mathrm{t}-1}+\varepsilon_{1 \mathrm{t}}
\end{aligned}
$$

şeklinde ifade edilebilir. Hata düzeltme modelinde yer alan $\partial_{i}$ hata düzeltme katsayısını ifade etmektedir.

Yapılan analizin ilk aşamasında, panel grubunu oluşturan ülkeler arasında yatay kesit bağımlılığının sınaması yapılmaktadır. Bu çerçevede, uygulanan yatay kesit bağımlılığı testi sonuçları Tablo 1'de yer almaktadır. 
Tablo 1. Yatay Kesit Bağımlılı̆̆ı Testi Sonuçları

\begin{tabular}{|l|l|}
\hline & T-istatistiği \\
\hline CD $_{\text {LM }}$ & $4.686 * * *$ \\
\hline
\end{tabular}

Not:***, \%1 düzeyinde istatistiki anlamlılığı ifade etmektedir.

Yapılan yatay kesit bağımlılı̆̆ı testlerine göre, elde edilen sonuçlar, her iki ülke grubu için yatay kesit bağımlılığının yani ülke ekonomileri arasında ekonomik ve finansal bakımdan bağlantıların söz konusu olduğunu göstermektedir. Ülkeler arasında yatay kesit bağımlılığının söz konusu olması dolayısıyla panel grubunu oluşturan ülkeler arasında yatay kesit bağımlılı̆̆ına izin veren Pesaran (2007) tarafindan önerilen CIPS birim kök testinden faydalanılmıştır.

Tablo 2. Birim Kök testi sonuçları

\begin{tabular}{ll}
\hline \hline & \\
\hline $\mathrm{LnCO}_{2}$ & $-3.464 * * *$ \\
$\Delta \mathrm{LnCO}_{2}$ & - \\
\hline $\mathrm{LnGSYH}$ & -0.645 \\
$\Delta \mathrm{LnGSYH}$ & $-3.399 * * *$ \\
\hline $\mathrm{LnGSYH}^{2}$ & -0.486 \\
\hline$\Delta \mathrm{LnGSYH}^{2}$ & $-3.315^{* * *}$ \\
\hline LnHDI & -1.301 \\
\hline$\Delta \mathrm{LnHDI}$ & $-3.554 * * *$ \\
\hline
\end{tabular}

Not:***, \%1 düzeyinde istatistiki anlamlılığ ifade etmektedir.

Yapılan birim kök testi sonuçlarına göre, $\mathrm{LnCO}_{2}$ değişkeni haricindeki diğer değişkenler için serilerin düzey değerlerinde birim kök içerdiği yönündeki " $\mathrm{H}_{0}$ : Seriler Durağan Değildir" hipotezinin reddedilemediği, fark değerleri ile tekrar yapılan birim kök testi sonuçlarında ise tüm değişkenler için kurulan boş hipotezin reddedildiği ve serilerin durağan hale geldiğ sonucuna ulaşılmıştır. Bu doğrultuda GSYH, GSYH ${ }^{2}$ ve HDI serilerinin I(1) diğer bir ifade ile birinci mertebeden bütünleşik olduğu söylenebilir. $\mathrm{LnCO}_{2}$ değişkeni için yapılan birim kök testi sonuçları ise serinin düzeyde durağan diğer bir ifade ile $\mathrm{I}(0)$ olduğunu ortaya koymaktadır.

Modelde yer alan değişkenlerin farklı düzeyden durağan olması, değişkenler arasındaki uzun dönemli ilişkinin tespit edilmesinde ARDL modelinin kullanılmasında gerekçe olarak gösterilebilir. Uygulanan tahmincilerin bulguları Tablo 3'te yer almaktadır. 
Tablo 3. Panel ARDL Tahmin Sonuçları

\begin{tabular}{|c|c|c|}
\hline & PMG & MG \\
\hline Uzun Dönem & & \\
\hline $\operatorname{lnGSYH}$ & $0.30^{* * *}$ & $2.788^{* *}$ \\
\hline $\operatorname{lnGSYH}{ }^{2}$ & $-0.057^{* * *}$ & $-1.444^{* *}$ \\
\hline LnHDI & $-7.966^{* * *}$ & $-5.763^{* * *}$ \\
\hline Hata Düzeltme Katsayıs1 \\
\hline ECT (-1) & $-0.17^{* *}$ & 1.14 \\
\hline
\end{tabular}

Tablo 3'te yer alan bulgular incelendiğinde, GSYH, GSYH ${ }^{2}$ ve HDI değişkenlerini $\mathrm{CO}_{2}$ üzerindeki uzun dönemli etkisini gösteren tahminci katsayılarının farklılık gösterdiği görülmektedir. $\mathrm{Bu}$ doğrultuda, Panel ARDL/PMG ve Panel ARDL/MG tahmincisi katsayılarının hangisinin kullanılan model çerçevesinde geçerli olduğunun tespit edilmesi gerektiğinden çalışmanın devamında Hausman Testi yapılmıştır. Yapılan Hausman Testi sonuçları Tablo 4 'te yer almaktadır. Hausman testi sonuçlarına göre elde edilen olasılık değerlerinin $\% 5$ 'te küçük ve $\% 5$ 'ten büyük olması durumunda sirasılyla, Panel ARDL/MG ve Panel ARDL/PMG tahmincisi bulgularının kullanılması gerekmektedir. Tablo 4'te elde edilen sonuçlar, tahminci katsayıları olarak Panel ARDL/PMG bulgularının kullanılması gerektiğini göstermektedir.

Tablo 4. Hausman Testi Sonuçları

\begin{tabular}{|l|l|l|}
\hline Tahminci & Chi2 & Olas1lık \\
\hline MG,PMG & 1.05 & 0.78 \\
\hline
\end{tabular}

Panel ARDL/PMG sonuçlarına göre, $\mathrm{CO}_{2}$ değişkeni, GSYH değişkenindeki artıştan pozitif yönde, HDI değişkenindeki artıştan ise, negatif yönde etkilenmiştir. Ayrıca, $\mathrm{CO}_{2}$ 'yi etkileyen bir diğer değişken olarak modele dahil olan GSYH ${ }^{2}$ değişkenin katsayısının negatif yönlü olması, seçilen ülkelerde EKC hipotezinin geçerli olduğunu, ekonomik büyümeye bağlı olarak uzun dönemde, $\mathrm{CO} 2$ emisyonu ile ekonomik büyüme arasındaki ilişkinin negatif yönlü olduğunu göstermektedir. Ayrıca HDI değişkeninin $\mathrm{CO} 2$ emisyonunu negatif yönde etkilemesi bu ülkelerde çeşitli sosyo- ekonomik alanlarda gerçekleşecek olan iyileşmelerin karbon emisyonunu azaltacağını göstermektedir. Bununla birlikte elde edilen Panel ARDL/PMG bulguları, belirlenen model için hata düzeltme mekanizmasının işlediğini ifade etmektedir. Elde edilen bulgular, Gürlük (2009) çalışmalarında elde edilen sonuçlar ile tutarlıdır. 


\section{SONUÇ}

Yapılan çalışmada, Avrupa Birliğinde yer alan Akdeniz Ülkeleri Hırvatistan, Kıbrıs, Fransa, Yunanistan, İtalya, Malta, Slovenya, İspanya ve birlik içerisinde yer almayan Türkiye için 1998-2014 yılları arasındaki ekonomik büyüme, karbon emisyonu ve insani gelişmişlik düzeyi arasındaki ilişkinin test edilmesi ve bu doğrultuda ülkelerin kalkınma stratejilerinin sürdürülebilir büyümeye katkısı hakkında bilgi edinilmesi amaçlanmaktadır. Belirlenen ülkelerde Çevresel Kuznets Eğrisi (EKC)hipotezinin geçerli olup olmadığı sınanmış ve karbon emisyonu ile insani gelişmişlik düzeyi arasındaki ilişki test edilmiştir. $\mathrm{Bu}$ çerçevede, yatay kesit bağımlılığına sahip olan ülkelerden oluşan seçilmiş ülke grubunun göstergeleri arasındaki ilişkinin incelenmesi amacıyla Panel ARDL yönteminden faydalanılmıştır. Elde edilen sonuçlar belirlenen ülkelerin karbon emisyonlarının GSYH artışından pozitif yönde etkilenirken uzun dönemde negatif yönde etkilendiğini, ülkelerin karbon emisyonları ile İnsani Gelişmişlik İndeksi (HDI) göstergesi arasında negatif yönlü bir ilişkinin söz konusu olduğunu ve dolayısıyla EKC hipotezinin geçerli olduğunu ortaya koymaktadır. Bu çerçevede seçilen ülkelerin gelişmelerine paralel olarak çevre tahribatı veya kirliğini temsil eden göstergelerin azaldığı sonucuna ulaşılmaktadır. Elde edilen sonuçlar, seçilmiş Akdeniz bölgesi ülkelerinin sanayileşme süreçlerini, uyguladıkları çevre dostu politikalar ile sürdürdüğüne işaret etmektedir.

\section{KAYNAKLAR}

Ahmed, Khalid ve Wei Long (2012), " Environmental Kuznets Curve and Pakistan: An Empirical Analysis", Procedia Economics and Finance, 1, ss.4-13.

Ajmi, Ahdi Noomen; Hammoudeh, Shawkat; Nguyen, Duc Khuong ve Sato, Joao Ricardo (2015), “On the relationships between CO2 emissions, energy consumption and income: the importance of time variation.” Energy Economics, 49, ss.629-638.

Akbostanc1, Elif; Türüt Aşık, Serap ve G. İpek Tunç (2009), "The Relationship Between Income and Environment in Turkey: Is There An Environmental Kuznets Curve?", Energy Policy, 37(3), ss.861-867.

Apergis, Nicholas ve İlhan Özturk (2015), "Testing Environmental Kuznets Curve Hypothesis in Asian Countries", Ecological Indicators, 52, ss.16-22.

Aydın, Celil ve Ömer Esen (2017), "The Validity of the Environmental Kuznets Curve Hypothesis for CO2 Emissions in Turkey: New 
Evidence from Smooth Transition Regression Approach", Mustafa Kemal University Journal of Social Sciences Institute, 14(39), ss.101-116.

Başar, Selim ve M. Sinan Temurlenk (2007),"Çevreye Uyarlanmış Kuznets Eğrisi: Türkiye Üzerine Bir Uygulama", Atatürk Üniversitesi İktisadi ve İdari Bilimler Dergisi, 21(1), ss.1-12.

Bedir, Serap ve Vildan Merve Yilmaz (2016), "CO2 Emissions and Human Development in OECD Countries: Granger Causality Analysis With A Panel Data Approach.", Eurasian Economic Review, 6(1), ss.97-110.

Bello, Mufutau Opeyemi; Sakiru Adebola Solarin ve Yuen Yee Yen (2018), “The Impact of Electricity Consumption on CO2 Emission, Carbon Footprint, Water Footprint And Ecological Footprint: The Role of Hydropower in an Emerging Economy", Journal of Environmental Management, 219, ss.218-230.

Boutaud, Aurélien; Natacha Gondran ve Christian Brodhag (2006), “Local Environmental Quality Versus (Global) Ecological Carrying Capacity: What Might Alternative Aggregated İndicators Bring To The Debates About Environmental Kuznets Curves and Sustainable Development?”, International Journal Of Sustainable Development, 9(3), ss.297-310.

Bölük, Gülden ve Mehmet Mert (2015), “The Renewable Energy, Growth and Environmental Kuznets Curve in Turkey: An ARDL Approach”, Renewable and Sustainable Energy Reviews, 52, ss.587-595.

Carson, Richard T.; Yongil Jeon ve Donald R. McCubbin (1997), "The Relationship Between Air Pollution Emissions and Income: Us Data”, Environment and Development Economics, 2(4), ss.433-450.

Chen, Dongjing; Ma, Xiaoyan; Mu, Hairong ve Li, Peiying (2010), “The Inequality of Natural Resources Consumption and Its Relationship With The Social Development Level Based on The Ecological Footprint and The HDI", Journal of Environmental Assessment Policy and Management, 12(1), ss.69-86.

Grossman, Gene M. ve Alan B. Krueger (1991), "Environmental Impacts of A North American Free Trade Agreement”, National Bureau of Economic Research, w3914.

Grossman, Gene M. ve Alan B. Krueger (1995), "Economic Growth and The Environment”, Quarterly Journal of Economics, 110, ss.353-377. 
Gürlük, Serkan (2009), "Economic Growth, Industrial Pollution and Human Development in The Mediterranean Region”, Ecological Economics, 68(8-9), ss.2327-2335.

Harbaugh, William T.; Arik Levinson ve David Molloy, Wilson (2002), "Reexamining The Empirical Evidence for an Environmental Kuznets Curve”, Review of Economics and Statistics, 84(3), ss.541-551.

Jebli, Mehdi Ben; Youssef, Slim Ben ve Özturk, İlhan (2016), “Testing Environmental Kuznets Curve Hypothesis: The Role of Renewable and Non-Renewable Energy Consumption and Trade in OECD Countries”, Ecological Indicators, 60, ss.824-831.

Katircioğlu, Salih Turan ve Taşpinar, Nigar (2017), “Testing The Moderating Role of Financial Development in an Environmental Kuznets Curve: Empirical Evidence From Turkey", Renewable and Sustainable Energy Reviews, 68, ss.572-586.

Ketenci, Natalya (2018), “The Environmental Kuznets Curve in The Case of Russia”, Russian Journal of Economics, 4(3), ss.249-265.

Khanna, Neha ve Plassmann, Florenz. (2004), “The Demand For Environmental Quality and The Environmental Kuznets Curve Hypothesis”, Ecological Economics, 5(3-4), ss.225-236.

Kuznets, Simone (1955), “Economic Growth and Income Inequality”, The American Economic Review, 45(1), ss.1-28.

Lebe, Fuat (2016), “Çevresel Kuznets Ĕgrisi Hipotezi: Türkiye için Eşbütünleşme ve Nedensellik Analizi”, Doğuş Üniversitesi Dergisi, 17(2), ss.177-194.

Lise, Wietze (2006), “Decomposition of CO2 Emissions Over 1980-2003 in Turkey”. Energy Policy, 34(14), ss.1841-1852.

Melikhova, Oksana ve Č́žžek, Jakub (2014), “Kuznets Inverted U-Curve Hypothesis Examined on Up-To Date Observations For 145 Countries”, Prague Economic Papers, 23(3), ss.388-410.

Moran, Daniel D.; Wackernagel, Mathis; A.Kitzes, Justin; H.Goldfinger, Steven ve Boutaudc, Aurélien (2008), "Measuring Sustainable DevelopmentNation By Nation”, Ecological Economics, 64(3), ss.470-474.

Orman, Sabri (2008), İktisadi Kalkınma Politikaları ve Değerler, Ekonomik Kalkınma ve Değerler, UTESAV (15-36), İstanbul. 
Ozcan, Burcu; Apergis, Nicholas ve Shahbaz, Muhammad (2018), “A Revisit of The Environmental Kuznets Curve Hypothesis For Turkey: New Evidence from Bootstrap Rolling Window Causality”, Environmental Science and Pollution Research, 25(32), ss.32381-32394.

Pesaran, M. Hashem (2004), "General Diagnostic Tests For Cross Section Dependence in Panels”, CESifo Working Paper 1229; IZA Discussing Paper 1240(970).

Pesaran, M. Hashem (2007), “A Simple Panel Unit Root Test in The Presence of Cross Section Dependence”, Journal of Applied Econometrics, 22(2), ss.265-312.

Pesaran, M. Hashem; Shin, Yongcheol ve Smith, P. Ron (1999), "Pooled Mean Group Estimation of Dynamic Heterogeneous Panels”, Journal of the American Statistical Association, 94(446), ss.621-634

Shafik, Nemat ve Bandyopadhyay, Sushenjit (1992), "Economic Growth and Environmental Quality: Time-Series and Cross-Country Evidence”, World Bank Publications, 904

Shahbaz, Muhammad; Dube, Smile; Özturk, İlhan ve Jalil, Abdul (2015), "Testing The Environmental Kuznets Curve Hypothesis in Portugal. International Journal of Energy Economics and Policy, 5(2), ss.475-481.

Shahbaz, Muhammad; Lean, Hooi Hooi veShabbira, Muhammad Shahbaz. (2012), "Environmental Kuznets Curve Hypothesis in Pakistan: Cointegration and Granger Causality", Renewable and Sustainable Energy Reviews, 16(5), ss.2947-2953.

Song, Tao; Zheng, Tingguo ve Tong, Lianjun. (2008), “An Empirical Test of The Environmental Kuznets Curve in China: A Panel Cointegration Approach”, China Economic Review, 19(3), ss.381-392.

Soytaş, Uğur; Sarı, Ramazan ve Ewing, T. Bradley (2007), “Energy Consumption, Income, and Carbon Emissions in The United States". Ecological Economics, 62(3-4), ss.482-489.

Tzeremes, Panayiotis (2018), “Time-Varying Causality Between Energy Consumption, CO2 Emissions, and Economic Growth: Evidence From US States”,Environmental Science and Pollution Research, 25(6), ss. $6044-6060$. 
UNDP (United Nations Development Programme), Human Development Data, http://hdr.undp.org/en/data, (07.02.2019).

WB (World Bank), World Development Indicators, https://databank.worldbank.org/source/world-development-indicators, (07.02.2019)

Yerdelen Tatoğlu, Ferda (2017), Panel Zaman Serileri Analizi, Beta Yayınları, İstanbul.

York, Richard A.; Rosa, Eugene ve Dietz, Thomas (2003), "Footprints on The Earth: The Environmental Consequences of Modernity”, Am Sociol Rev, 68(2), ss.279-300

Yurttagüler, İpek ve Kutlu, Sinem (2017), “Çevresel Kuznets Eğrisi'nin Ekonometrik Bir Analizi: Türkiye Örneği”, Alphanumeric Journal, 5(1), ss.115-126. 